\title{
A modified sensitive palladium-copper oxide and multiwalled carbon nanotubes electrochemical sensor for detection of ametridione pesticide
}

\author{
V. Bebi \\ Electroanalytical Lab, Department of Chemistry, Sri Venkateswara University, Tirupati - 517502 \\ (A.P.), India \\ P. Reddy Prasad \\ Electroanalytical Lab, Department of Chemistry, Sri Venkateswara University, Tirupati - 517502 \\ (A.P.), India

\section{K. Sudheer} \\ Department of Chemistry, PES University, Banglore - 560085 (Karnataka), India

\section{P. Sandhya} \\ Department of Chemistry, Sri Padmavati Mahila Visvavidyalayam, Tirupati - 517502 (A.P.), \\ India

\section{Nageswara Reddy} \\ Department of Chemistry, Government Degree \& P.G College, Puttur - 517583 (A.P.), India \\ N. Y. Sreedhar* \\ Electroanalytical Lab, Department of Chemistry, Sri Venkateswara University, Tirupati - 517502 \\ (A.P.), India \\ *Corresponding author email: sreedhar_ny@rediffmail.com
}

\section{How to Cite}

Bebi, V. et al. (2021). A modified sensitive palladium-copper oxide and multiwalled carbon nanotubes electrochemical sensor for detection of ametridione pesticide. Journal of Applied and Natural Science, 13(3), 798 - 806. https://doi.org/10.31018/ jans.v13i3.2531

\begin{abstract}
A glassy carbon electrode modified with sensitive palladium-copper oxide and multi-walled carbon nanotubes ( $\mathrm{Pd}-\mathrm{CuO} /$ MWCNTs) electrochemical nanosensor was used to detect ametridione pesticide in water samples. The morphological characteristics of Pd-CuO/MWCNTs were examined by Scanning electron microscope (SEM) and Energy dispersive $x$-ray analysis (EDX.) The ametridione pesticide under voltammetric investigation involves irreversible, four electron (4e) reduction, based on the protonation of the two carbonyl groups $(>\mathrm{C}=\mathrm{O})$. The voltammetric method was applied to detect ametridione in Britton-Robinson (BR) buffer solution at $\mathrm{pH} 5.0$ as a supporting electrolyte. The limits of detection, quantification and concentration ranges of the proposed method were $0.0796 \mu \mathrm{g} \cdot \mathrm{mL}^{-1}$ (signal/noise=3), $0.5560 \mu \mathrm{g} \cdot \mathrm{mL}^{-1}$ and 0.1 to $10.0 \mu \mathrm{g} \cdot \mathrm{mL}^{-1}$, respectively. The electrochemical sensor was successfully applied to detect ametridione in tap, agricultural run-off and river water samples showing $>98 \%$ mean recoveries.
\end{abstract}

Keywords: Ametridione, CuO, Morphology, Pesticide, Sensor

\section{INTRODUCTION}

Ametridione, 1-amino-3- (2,2- dimethylpropyl)-6-(ethylt hio)-1,3,5-triazine-2,4(1H,3H)-dione is a triazinone group of herbicides class (Forouzesh et al., 2015). Herbicides are the fastest-growing classes of agricultural chemicals that are extensively used throughout the world, owing to their high toxicity to pests (Beckie et al., 2006; Legere et al., 200). The use of these herbicides in agriculture leads to numerous benefits in production and an increase of quality (Sephenson et al., 1990). However, due to intense usage, there is a possibility of leakage of these toxic compounds into the environment through water and/ or soil (Rich et al., 2012). The residue of the herbicides long time exists in the environment and can generate pollution problems and potential hazards in human beings and animals (Selim et al., 2003; Rayburn et al., 2005). However, the promiscu- 
ous analysis reveals residues of such pesticides in natural water and in foodstuffs (Kniss, 2017). Hence, rapid, reliable and inexpensive pesticide sensing becomes essential for public health protection in environmental monitoring. Electrochemical analysis of pesticides offers simple, rapid and cost-effective methods with a little sample pre-treatment steps (Pourakbari et al., 2020; Costa et al., 2017).

Among electroanalytical techniques, electrical conductivity is a determining factor in the choice of electrode material (Koksoy et al., 2021; Gonçalves-Filho et al., 2020; Thiago et al., 2020). For more than a decade, the use of modified glassy carbon electrodes has been reported to be a good alternative when compared to other working electrodes for electro-analysis of organic and inorganic species (Baghayeri et al., 2021; Vieira da Silva et al., 2021; Bhvimane et al., 2019). Hence, there is a wide variety of modified electrodes, developed for the determination of pesticides such as polyaniline modified glassy carbon electrodes, nano titanium dioxide polymer film modified GCE and poly (4-amino 3-hydroxy naphthalene sulphonic acid) modified GCE and nano $\mathrm{TiO}_{2} /$ Nafion composite etc., (Khadem et al., 2020; Ha et al., 2013; Jian-Chun et al., 2011; Gamze et al., 1997; Dan et al., 2010; Esmail et al., 2020; Ben Ali Hassine et al., 2018). So, to improve the analytical figures of merit, there exists a need for highly sensitive sensors for early detection and accurate determination of ametridione pesticide in water samples. Accordingly, there are no electro-analytical reports concerning the determination of ametridione pesticide using Pd-CuO/MWCNTs modified glassy carbon electrode. The electrochemical characteristics of $\mathrm{Pd}-\mathrm{CuO} / \mathrm{MWCNTs}$ were thoroughly examined by cyclic and differential pulse voltammetry to elucidate the electro-catalytic ability of the modified glassy carbon electrode.

\section{MATERIALS AND METHODS}

\section{Apparatus \\ Motrohm Autolab B.V. Netherlands provided the Au- tolab PG STAT 101 for electrochemical measurements. The working electrode was a three-electrode setup that included a modified glassy carbon electrode. The refer- ence electrode was saturated $\mathrm{Ag} / \mathrm{AgCl} / \mathrm{KCl}$, while the counter electrode was Pt wire. The electrode surface morphology was carried out using a scanning electron microscope (SEM) of OXFORD INCA PANTA FET X3 CARL ZEISS from Japan. The $\mathrm{pH}$ meter model ELICO LI-120, supplied by ELICO Ltd. Hyderabad, India, was used to determine the $\mathrm{pH}$ of the buffer solution.}

\section{Reagents and solutions}

All the reagents of analytical grade or HPLC grade used in the present work were obtained from Merck Chemicals Ltd. Ametridione (99 \%) (Fig. 1.) was purchased from Siddarth Inc. Hyderabad, India. MWCNTs (i.d. xlength 2-15 $\mathrm{nm} \times 1-10 \quad \mu \mathrm{m}$ ) purchased from DropSens. Pesticide stock solutions (1000 ppm) and subsequent dilutions were made with ultrapure water on a regular basis and kept in the refrigerator. BrittonRobinson (BR) buffer solution (acetic, boric and phosphoric acids) was made according to the literature (Costa et al., 2017), and the $\mathrm{pH}$ values were adjusted ( $\mathrm{fm} 2.0$ to 12.0) by adding appropriate amounts of 1.0 mol L ${ }^{-1} \mathrm{NaOH}$ solution, and were employed as supporting electrolyte. All solutions were prepared by using ultra-purified water from a Millipore Milli-Q system (18.2 $\mathrm{M} \Omega \mathrm{cm}^{-1}$ ). All electrochemical experiments were performed at room temperature $\left(25 \pm 1^{\circ} \mathrm{C}\right)$.

\section{Sample collection and preparation of water samples}

River water samples were collected in the Swarnamukhi River at a depth of water $45 \mathrm{~cm}$, as well as agricultural run-off and tap water samples from randomly selected locations in the Srikalahasti rural area, Chittoor district, Andhra Pradesh. Water samples were collected in the amber glass flasks, acidified with $0.5 \mathrm{~mol} \mathrm{~L}^{-1}$ $\mathrm{H}_{2} \mathrm{SO}_{4}$, and filtered through a $0.45 \mu \mathrm{m}$ membrane. Aliquots of standard herbicide solution prepared in acetonitrile were solubilised directly in the water samples at two concentration levels $\left(10\right.$ and $\left.25 \mu \mathrm{g} \cdot \mathrm{mL}^{-1}\right)$ and these spiked samples were stored in the refrigerator. Before this analysis, the spiked samples were filtered through a $0.45 \mu \mathrm{m}$ membrane and the $\mathrm{pH}$ of samples was adjusted to 5.0 and the samples were subjected to the voltammetric analysis without any pretreatment step.

\section{Preparation of Pd-CuO and Pd-CuO/MWCNTs}

For the production of Palladium, $\mathrm{CuO}$ and palladium supported $\mathrm{CuO}$ nanoparticles Theobroma cacao $L$. seeds extract was used as both reducing and stabilising agent, and the nanocomposites were biosynthesised according to the literature approach (Nasrollahzadh et al., 2016). For the synthesis of Pd, $\mathrm{CuO}$ and $\mathrm{Pd} / \mathrm{CuO}$ nanocomposite, there is no surfactant, capping agent and template were utilised in this approach.

Prior to preparing $\mathrm{Pd}-\mathrm{CuO} / \mathrm{MWCNTs}$ nanocomposite, the MWCNTs were first oxidised in a $40 \mathrm{~mL}$ acidic combination of $\mathrm{H}_{2} \mathrm{SO}_{4} / \mathrm{HNO}_{3}$ with a $3: 1$ ratio, then ultrasonicated for 5 hours. The oxidized MWCNTs were filtered and washed several times with ultra-pure water to eliminate the acidic contents, and then vacuum dried at $80{ }^{\circ} \mathrm{C}$ overnight. After that, the dried oxidized MWCNTs and Pd-CuO were sonicated for $30 \mathrm{~min}$ in acetone. The freshly generated Pd-CuO/MWCNTs nanocomposites were filtered and dried at $80{ }^{\circ} \mathrm{C}$ for 1 h. in a vacuum oven, then heated at $1^{\circ} \mathrm{C} / \mathrm{min}$ to at $200^{\circ}$ $\mathrm{C}$ in an oven. For comparison, $\mathrm{Pd}$ and $\mathrm{CuO}$ supported MWCNTs nanocomposites were also synthesized. 


\section{Preparation of Pd-CuO/MWCNTs/GCE}

The GCE was first cleaned using $0.3 \mu \mathrm{m}$ alumina powder using a BAS polishing kit followed by an ultrasonic bath in ethanol for $10 \mathrm{~min} .10 \mathrm{mg}$ of Pd-CuO/MWCNTs nanocomposites was ultrasonicated in $10 \mathrm{~mL}$ acetone and $10 \mu \mathrm{L}$ of Pd-CuO/MWCNTs was then dropped on the surface of cleaned GCE and dried under the lamp for 30 minutes and rinsed in ultra-pure water several times. A similar procedure was repeated to modify the GCE with Pd, CuO and MWCNTs sensor for the electrocatalytic reduction of pesticide. Modified GCE was washed with ultrapure water and dried at room temperature for voltammetry study. A volume of $10.0 \mathrm{~mL}$ of Britton-Robinson (BR) buffer was added to the electrochemical cell for the experiments. Before the voltammetric measurements, the electrochemical solution was deoxygenated for 5 min using nitrogen gas.

\section{RESULTS AND DISCUSSION}

The morphology of the Pd-CuO/MWCNTs nanocomposites was investigated through the Scanning electron microscope technique (Fig. 2). The surface observed for the electrode fabricated with $\mathrm{Pd}, \mathrm{CuO}$ and $\mathrm{Pd}-\mathrm{CuO} /$ MWCNTs, appeared to be rougher, irregular in shape and size, which indicated that surface area was very large in SEM analysis (Fig. 2a \& 2b). The palladium nanoparticles were observed in spherical shapes or clusters on the surface of MWCNTs with a diameter of around $\sim 60 \mathrm{~nm}$. However, the presence of patterned structures generated by globular crystals, which may be associated with the formation of aggregated particles. The diameter of a meandering form of carbon nanotubes was in the range of $10 \mathrm{~nm}$, while the length could reach more than several micrometres. Fig. 2c clearly shows that Pd-CuO/MWCNTs with the granular structure were distributed on the GCE surface, whereas the bare GCE displayed a relatively smooth surface. Thus, MWCNTs on the electrode contributed to the enhancement of the surface area. The $\mathrm{Pd}-\mathrm{CuO} /$ MWCNTs surface also was analysed by EDX and the results are shown in Fig. 3. The EDX spectroscopy<smiles>CCSc1nc(=O)n(CC(C)(C)C)c(=O)n1N</smiles>

Fig. 1. Chemical structure of ametridione pesticide (Cho udhury et al., 2016).

showed that the nanocomposites were mainly composed of $\mathrm{Cu}, \mathrm{Pd}, \mathrm{C}$ and $\mathrm{O}$ elements.

The glassy carbon electrode was modified with $\mathrm{Pd}$, MWCNTs, CuO and Pd-CuO/MWCNTs nanocomposites. Pd-CuO supported MWCNTs modified electrode for ametridione detection was improved in terms of sensitivity, stability and mechanical asset. The cyclic voltammograms of ametridione $\left(6.0 \mu \mathrm{g} \cdot \mathrm{mL}^{-1}\right)$, in Britton -Robinson buffer at pH 5.0 and scan rate $50 \mathrm{mVs}^{-1}$. Fig. 4 compares cyclic voltammograms of $\left(6.0 \mu \mathrm{g} \cdot \mathrm{mL}^{-1}\right)$ ametridione at bare GCE, CuO/GCE, MWCNTs/GCE, $\mathrm{Pd} / \mathrm{GCE}$ and $\mathrm{Pd}-\mathrm{CuO} / \mathrm{MWCNTS/GCE}$. The reduction peak appeared at $-1.12 \mathrm{~V}$, which was due to the reduction of two carbonyl groups of the ametridione and no oxidation peak was observed in the anodic branch that suggested that the process was irreversible. The cyclic voltammogram of Pd-CuO/MWCNTs/GCE in Fig. 4e reveals a significant background current, which indicated that the electrode had been effectively modified as seen by the substantial double-layer charging current. The CuO/GCE (Fig. 4b) did not exhibit a significant variation in their background currents compared to the MWCNTs (Fig. 4c). As shown in the figure, the peaks of pesticide at different potentials and the lowest peak potential were $-1.12 \mathrm{~V}$ for the electrode $\mathrm{Pd}-\mathrm{CuO} /$ MWCNTs/GCE, which was significant than the unmodified GCE. When the peak current of ametridione was compared at these electrodes, the maximum peak current was $24.38 \mu \mathrm{A}$, corresponding to the electrode of $\mathrm{Pd}-\mathrm{CuO} / \mathrm{MWCNTS/GCE}$. This value was larger five times compared with the value recorded for the unmod-

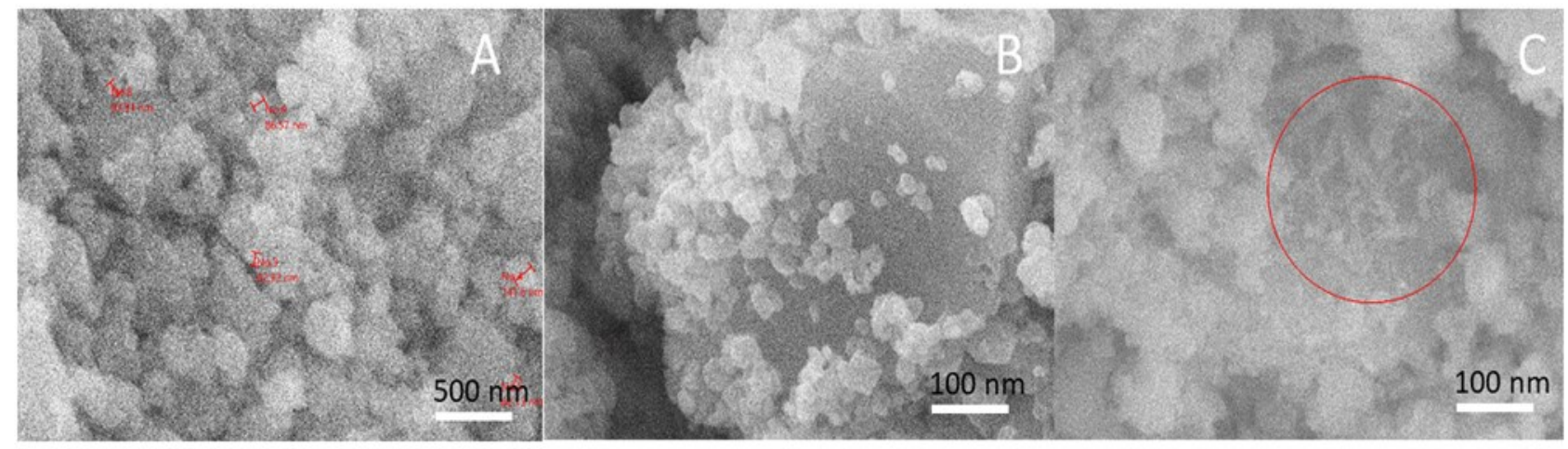

Fig. 2. Scanning electron microscope images of $P d(A), C u O(B)$ and $P d-C u O$ supported MWCNTs. 


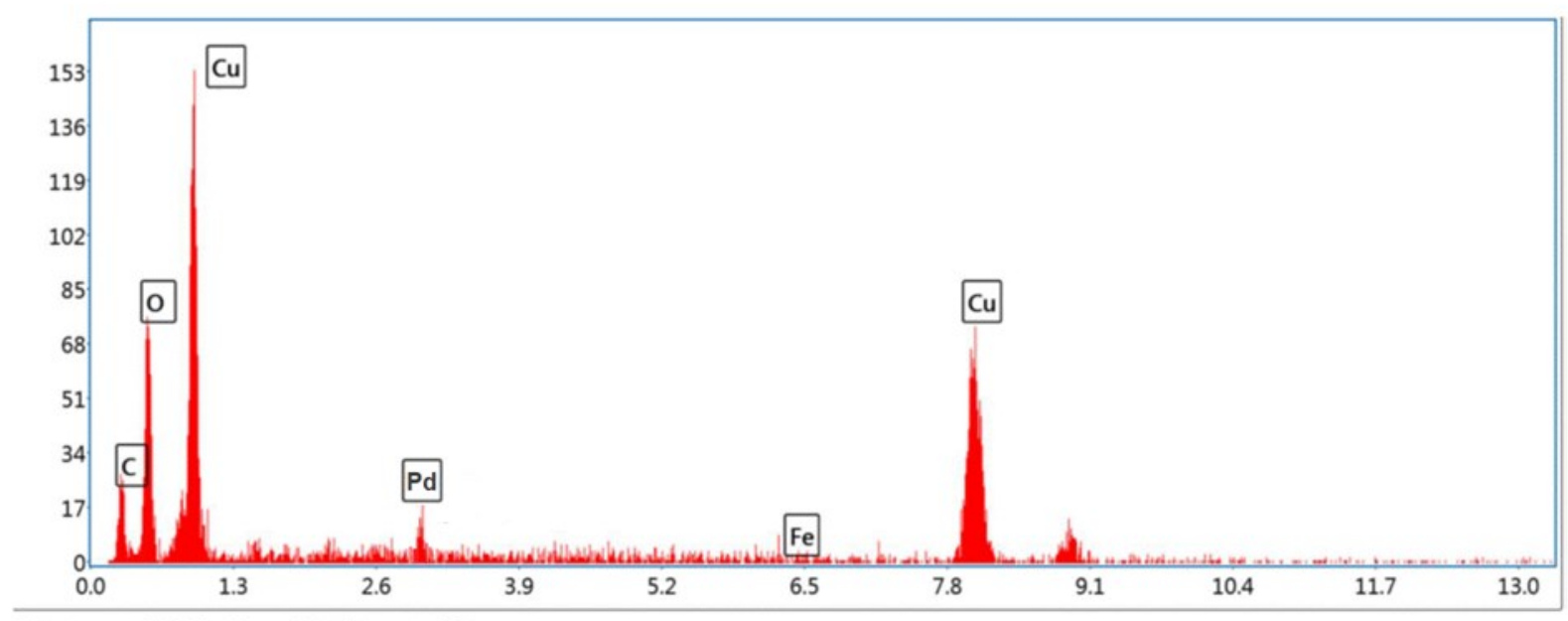

2 Cnts $1.070 \mathrm{keV} \quad$ Det: Element-C2B

Fig. 3. EDX spectrum of Pd-CuO supported MWCNTs.

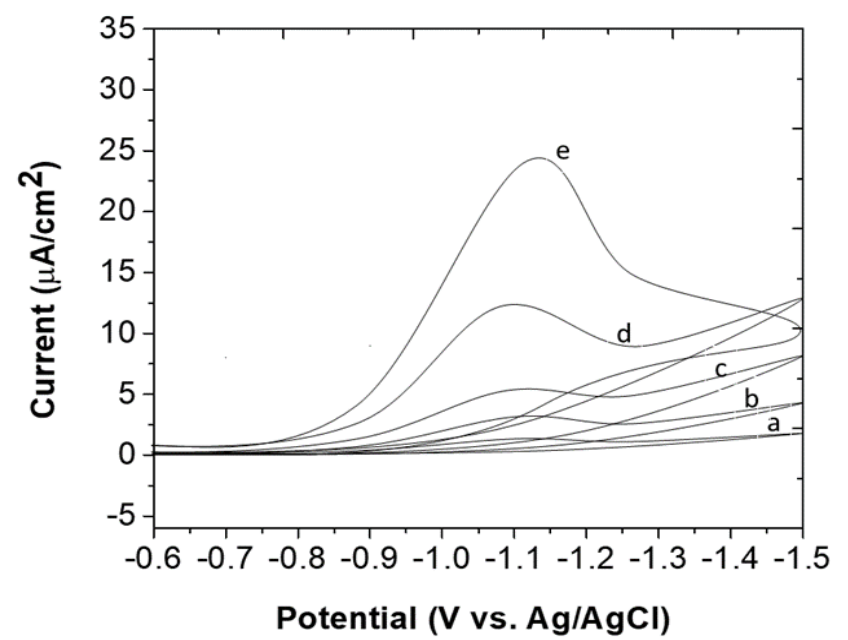

Fig. 4. Cyclic voltammograms for $5.0 \mu \mathrm{g} \cdot \mathrm{mL}^{-1}$ ametridione at bare GCE (a), Cuo/GCE (b), MWCNTs/GCE (c), Pd/ GCE (d) and Pd-CuO/MWCNTs/GCE (e) in pH 5.0 (0.10 $M$ of BR buffer); accumulation potential $-1.1 \mathrm{~V}$, accumulation time $100 \mathrm{~s}$, pulse amplitude $50 \mathrm{mV}$ and the scan rate $40 \mathrm{mV} \mathrm{s}^{-1}$.

ified bare GCE (Fig. 4a). The CuO/GCE (Fig. 4b) and MWCNTs/GCE (Fig. 4c) also showed improvement in the peak current of ametridione as twice as that of bare GCE, whereas the current for CuO/GCE was not significantly different to bare GCE. On the basis of the above results, the $\mathrm{Pd}-\mathrm{CuO}$, supported MWCTs was successfully immobilised on the GCE surface and synergistic electro-active character. Additionally, the electrochemical sensor provided high electro-catalytic activity because of their large surface area and an efficient electron transfer.

The differential pulse voltammetric response of 6.0 $\mu \mathrm{g} \cdot \mathrm{mL}^{-1}$ ametridione studied at $\mathrm{Pd}-\mathrm{CuO} / \mathrm{MWCNT}$ s with Britton-Robinson buffer at $\mathrm{pH} 5.0$ as a supporting electrolyte the pulse amplitude of $30 \mathrm{mV}$ and scan rate of $50 \mathrm{mVs}^{-1}$ is shown in Fig. 5. At bare GCE (Fig. 5a), no obvious reduction peak was attained for $6.0 \mu \mathrm{g} \cdot \mathrm{mL}^{-1}$

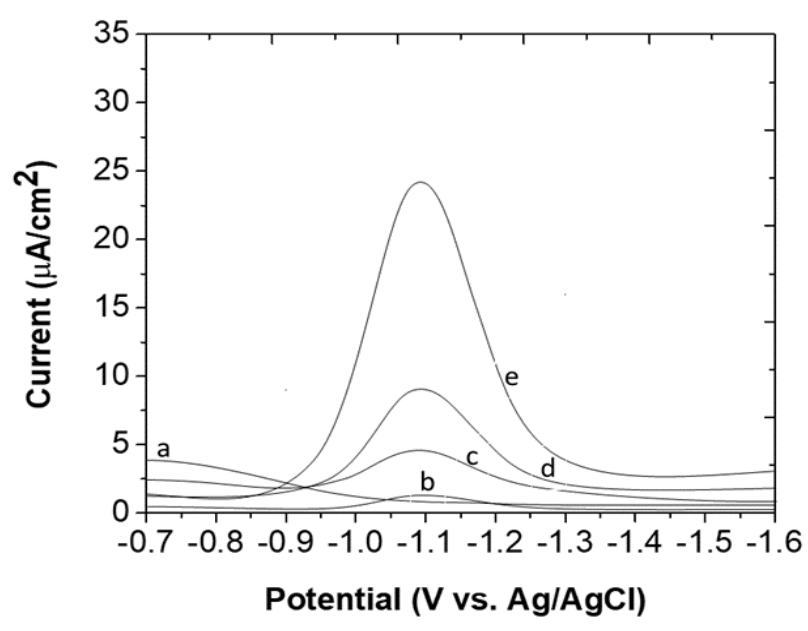

Fig. 5. Differential pulse voltammograms for $6.0 \mu \mathrm{g} \cdot \mathrm{mL}^{-1}$ ametridione at bare GCE (a), Cuo/GCE (b), MWCNTs/ GCE (c), Pd/GCE (d) and Pd-CuO/MWCNTs/GCE (e) in pH 5.0 (0.10 M of BR buffer); accumulation potential -1.1 $V$, accumulation time $100 \mathrm{~s}$, pulse amplitude $50 \mathrm{mV}$ and the scan rate $40 \mathrm{mV} \mathrm{s}^{-1}$.

ametridione $\mathrm{pH}$ 5.0. At fabricated CuO/GCE (Fig. 5b) and MWCNTs/GCE (Fig. 5c), the small reduction peak current was observed expressively significant than the bare GCE reduction current. The Pd/GCE (Fig. 5d) showed a respectable reduction peak current that appeared due to great electron mobility. Furthermore, the enrichment of the reduction peak current of the PdCUO/MWCNTs modified GCE, was acquired owing to the expectant area and great electrical conductibility of the ametridione (Fig. 5e). Therefore, the differential pulse voltammograms were observed for bare GCE, CuO/GCE, Pd/GCE, and MWCNTs/GCE. It was found not to be so effective for reducing ametridione.

\section{Optimum parameters on the response of ametridione}

The influence of $\mathrm{pH}$ of the medium significantly enhanced the reduction of the peak current of ametridi- 


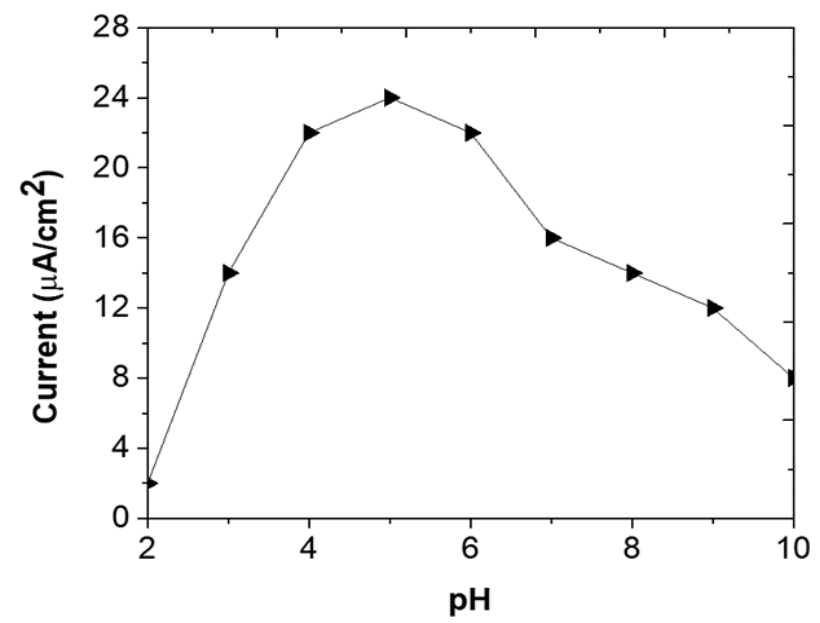

Fig. 6. Effect of $\mathrm{pH}$ on the electrochemical response of the $\mathrm{Pd}$-CuO/MWCNTS/GCE. accumulation potential $-1.1 \mathrm{~V}$, accumulation time $100 \mathrm{~s}$, pulse amplitude $50 \mathrm{mV}$ and the scan rate $40 \mathrm{mV} \mathrm{s}^{-1}$.

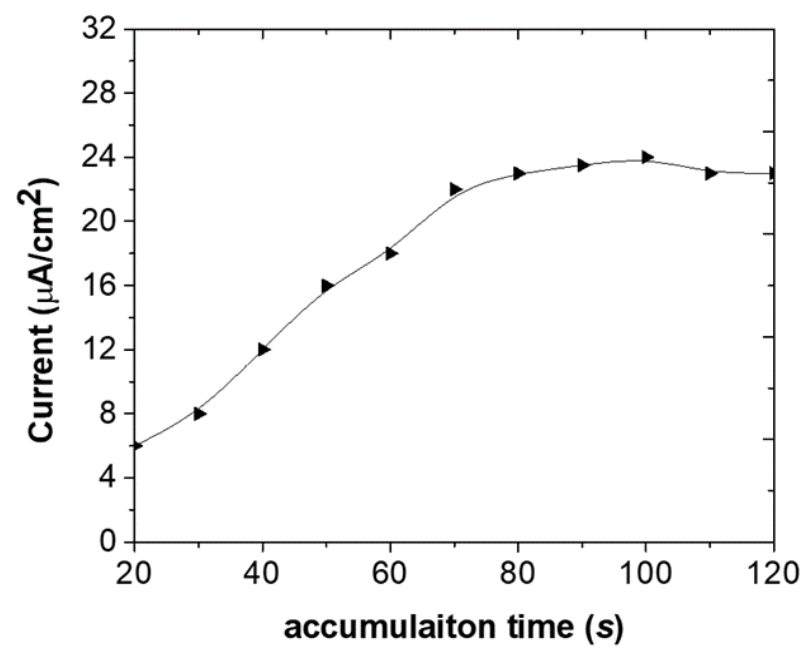

Fig. 8. Effect of accumulation time on the electrochemical response of ametridione at Pd-CuO/MWCNTs/GCE; accumulation potential $-1.1 \mathrm{~V}$, pulse amplitude $50 \mathrm{mV}$ and the scan rate $40 \mathrm{mV} \mathrm{s}^{-1}$.

one. The effect of $\mathrm{pH}$ on the reduction peak current of ametridione investigated in the range of $\mathrm{pH} 2.0-12.0$ with Britton-Robinson buffer indicated that process, responsible for this behaviour, must be the reduction of the carbonyl group in the ametridione and the maximum peak, which was observed at $\mathrm{pH} 5.0$ on $\mathrm{Pd}-\mathrm{CuO} /$ MWCNTS/GCE. It indicates that the proton concentration in the acidic solution was superior for the reduction of carbonyl group of ametridione. Moreover, the peak potential of ametridione shifted negatively constantly with the increase of $\mathrm{pH}$ and as seen in Fig. 6. As a result, Britton-Robinson buffer ( $\mathrm{pH}$ 5.0) was considered as the most suitable accompanying electrolyte for further investigation. Through the electrochemical reduc-

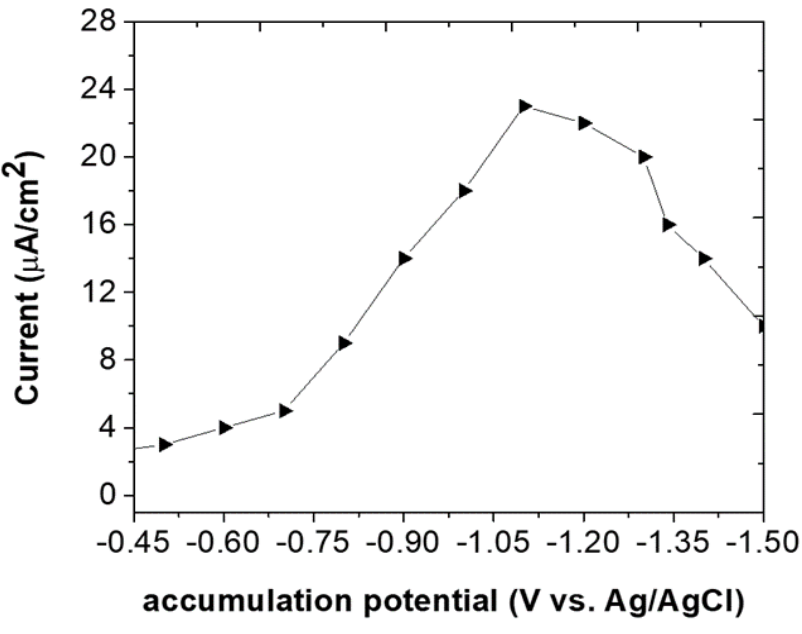

Fig. 7. Effect of accumulation potential on the electrochemical response of ametridione at Pd-CuO/MWCNTs/ GCE; accumulation time $100 \mathrm{~s}$, pulse amplitude $50 \mathrm{mV}$ and the scan rate $40 \mathrm{mV} \mathrm{s}^{-1}$.

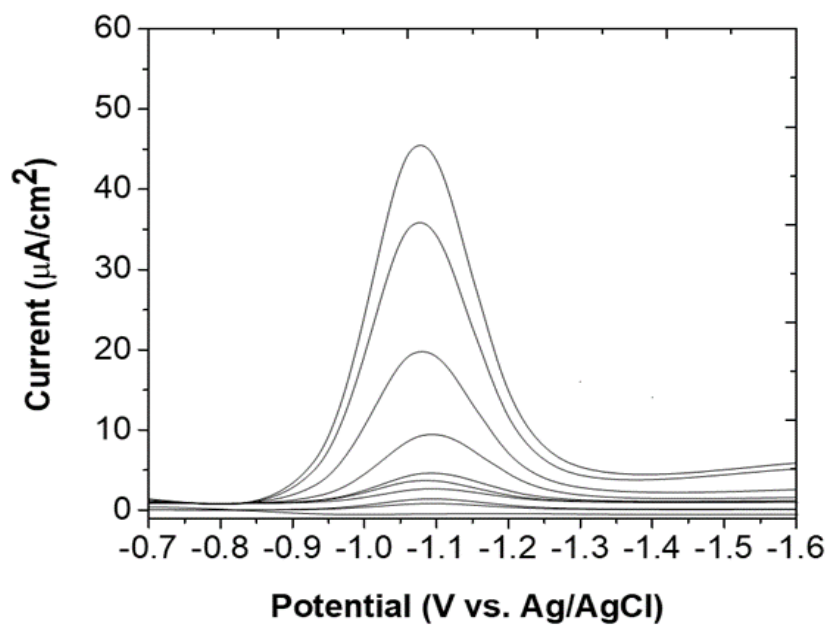

Fig. 9. Differential pulse voltammograms recorded at $P d-$ CUO/MWCNTS/GCE for different concentrations of ametridione $(0,0.1,0.2,0.4,0.8,1.0,2.0,4.0,8.0$ and 10.0 $\mu \mathrm{g} \cdot \mathrm{mL}^{-1}$ (from bottom to top)); in pH 5.0 (BR buffer); accumulation potential $-1.1 \mathrm{~V}$, accumulation time $100 \mathrm{~s}$, pulse amplitude $50 \mathrm{mV}$ and the scan rate $40 \mathrm{mV} \mathrm{s}^{-1}$.

tion of ametridione, the $\mathrm{pH}$ implies protonation of the reactive portion of the molecule. This behaviour suggests that protons are involved in chemical processes during the electrochemical reduction of ametridione. Based on these results, Scheme 1 depicts an electrochemical reduction of ametridione involving the same number of protons and electrons.

The optimisation of the differential pulse voltammetry parameters is essential to achieve the best conditions of the electrochemical analysis of ametridione at $\mathrm{Pd}$ CuO/MWCNTs/GCE electrode. The effect of scan rate on the differential pulse voltammetric responses at $\mathrm{Pd}$ CuO/MWCNTs/GCE using Britton-Robinson buffer as a supporting electrolyte showed that the scan rate, the 


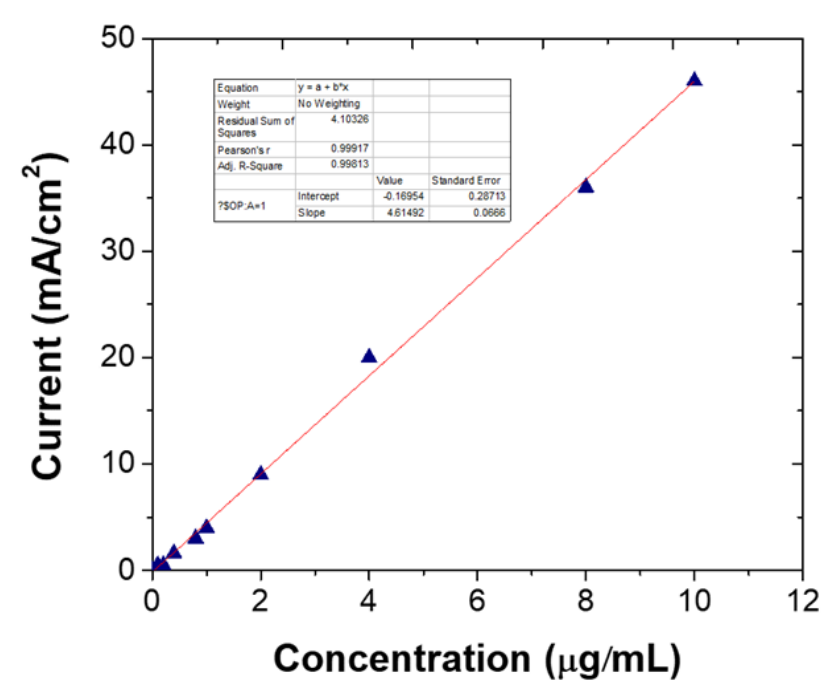

Fig.10. Calibration curve of ametridione at $\mathrm{Pd}-\mathrm{CuO} /$ MWCNTS/GCE; in pH 5.0 (BR buffer); accumulation potential $-1.1 \mathrm{~V}$, accumulation time $100 \mathrm{~s}$, pulse amplitude $50 \mathrm{mV}$ and the scan rate $40 \mathrm{mV} \mathrm{s}^{-1}$.

current response, and increasing the scan rate from 0 $\mathrm{mVs}^{-1}$ to $150 \mathrm{mVs}^{-1}$, such gave the maximum response at $50 \mathrm{mVs}^{-1}$. The reduction peak of ametridione is observed in the potential range of $-0.5-1.6 \mathrm{~V}$ shifting more towards negative potential with an increasing scan rate. The deposition potential was chosen at $-1.11 \mathrm{~V}$, which corresponds to the reduction potential for ametridione under optimum conditions (Fig. 7). This intriguing study indicated electrochemical reduction of ametridione pesticide products on DPV's maximum peak current. Hence, the enhanced absorption and the accumulation of ametridione on the Pd-CuO/MWCNTs/GC electrode after its pre-treatment at $-1.1 \mathrm{~V}$ can be exploited here to increase the sensitivity of the DPV significantly. Fig. 8 shows that the signal has a prolongation of the accumulation time up to $100 \mathrm{~s}$. The peak current increased rapidly with the increase of accumulation time and almost reached a platform after $100 \mathrm{~s}$. For analytical purposes, Pd-CuO/MWCNTs/GC electrode was initially pre-treated for $100 \mathrm{~s}$ into the solution of $6.0 \mu \mathrm{g} \cdot \mathrm{mL}^{-1}$ of ametridione. Before it was used for measuring the concentration of ametridione to achieve down to the low ppm-level, Britton-Robinson buffer solution was used. The additional preconcentration time of $100 \mathrm{~s}$ was em-
Table 1. Results for the interference study regarding some inorganic and biomolecules on the voltammetric reduction of $6.0 \mu \mathrm{g} \cdot \mathrm{mL}^{-1}$ at Pd-CuO/MWCNTs/GCE.

\begin{tabular}{ll}
\hline Interfering species & Tolerance $\left(\boldsymbol{\mu g} \cdot \mathrm{mL}^{-1}\right)^{*}$ \\
\hline $\mathrm{Na}^{+}, \mathrm{NH}_{4}{ }^{+}$ & 1000 \\
$\mathrm{OH}^{-}, \mathrm{CO}_{3}{ }^{2-}, \mathrm{SO}_{4}{ }^{2-}, \mathrm{PO}_{4}{ }^{3-}, \mathrm{Cl}^{-}$ & 1000 \\
Citric acid & 500 \\
Ascorbic acid & 400 \\
Urea & 300 \\
Thiodicarb & 20 \\
\hline
\end{tabular}

*the level with maximum concentration of foreign for deviation less than $\pm 5 \%$.

ployed before each measurement. The selected pretreatment time is enough to obtain a stable analytical signal. Accordingly, the optimum conditions for recording a maximum developed and sharpened peak for ametridione are accumulation time $100 \mathrm{sec}$, accumulation potential $-1.1 \mathrm{~V}$, scan rate $50 \mathrm{mVs}-1$, pulse amplitude $30 \mathrm{mV}$, and optimum temperature $25^{\circ} \mathrm{C}$. Furthermore, it should be noted that $\mathrm{Pd}-\mathrm{CuO}$ nanoparticles are electro-catalyst which in synergism with a developed surface area of MWCNTs enables the successful application of this sensor for the determination of ametridione pesticide.

Under the voltammetric conditions, the selectivity of the $\mathrm{Pd}-\mathrm{CuO} / \mathrm{MWCNTs} / \mathrm{GCE}$ sensor was evaluated by testing its electrochemical response to $6.0 \mu \mathrm{g} \cdot \mathrm{mL}^{-1}(\mathrm{pH} 5.0)$ ametridione pesticide in the presence of interfering substances. The known amounts of $\mathrm{NH}_{4}^{+}, \mathrm{Na}^{+}, \mathrm{K}^{+}, \mathrm{Ca}^{2+}$, $\mathrm{Ag}^{+}, \mathrm{HCO}_{3}{ }^{-}, \mathrm{SO}_{4}{ }^{2-}, \mathrm{CO}_{3}{ }^{2-}, \mathrm{Cl}^{-}, \mathrm{NO}_{3}{ }^{-}$, urea, ascorbic acid and thiodicarb on the determination of ametridione in water samples indicated that the thiodicarb is one of the most common compounds that interacted with ametridione in water samples. The electrochemical reduction of ametridione had negligible influence with a twenty-fold excess of thiodicarb and the results are summarised in Table 1 . The developed sensor behaved selectively with respect to ametridione because there were no significant changes in the peak current for ametridione reduction $(< \pm 5 \%)$ in the presence of interfering species.<smiles>CCSc1nc(=O)n(CC(C)(C)C)c(=O)n1N</smiles><smiles>CCSC1=NC(O)N(CC(C)(C)C)C(O)N1N</smiles>

Scheme 1. Electrochemical reduction mechanism of ametridione. 
Bebi, V. et al. / J. Appl. \& Nat. Sci. 13(3), 798 - 806 (2021)

\section{Voltammetric performance on the determination ametridione}

Based on the optimised parameter, a typical differential pulse voltammogram recorded in various concentration ranged from $0.10 \mu \mathrm{g} \cdot \mathrm{mL}^{-1}$ to $10 \mu \mathrm{g} \cdot \mathrm{mL}^{-1}$ at $\mathrm{Pd}$ / MWCNTs/GCE as shown in Fig. 9. The peak currents showed a linear dependence on the concentration range from $0.10 \mu \mathrm{g} \cdot \mathrm{mL}^{-1}$ to $10 \mu \mathrm{g} \cdot \mathrm{mL}^{-1}$ of ametridione on Pd-CuO/MWCNTs/GCE. Fig.10 represents the calibration plot recorded using the standard addition method. The linear equation was $I(\mu \mathrm{A})=0.169+4.614 \mathrm{C}$ $\mu \mathrm{g} \cdot \mathrm{mL}^{-1}$ with a correlation coefficient of 0.998 . The detection limit $(\mathrm{LOD}=3(\mathrm{sd}) / \mathrm{b})$ and quantitation of limit $(\mathrm{LOQ}=10(\mathrm{sd}) / \mathrm{b})$ were determined, where sd being the standard deviation of the intercept and $b$ denoting the slope of the calibration graph. On Pd-CuO/MWCNTs/ GCE electrochemical sensor, the LOD and LOQ of ametridione were found to be $0.0796 \mu \mathrm{g} \cdot \mathrm{mL}^{-1}$ and $0.5560 \mu \mathrm{g} \cdot \mathrm{mL}^{-1}$, respectively.

The practicality of the developed method was validated by measuring ametridione in spiked samples of tap, agricultural runoff and river water. To avoid the matrix effect, the standard addition method was used to carry out the quantitative assays. Moreover, the determinations were performed in quintuple to check the precision of the assays. In order to check the precision of the method, five replicate analyses of each sample, were carried out. The average recoveries obtained in water samples were $97.6-99.9 \%$ (Table 2 ) with a relative standard deviation of $1.69 \%$, respectively. The suggested electrochemical characteristics, such as dynamic range, $L O D$ and $L O Q$ are compared with other conventional metaloxide-based sensors as shown in Table 3. Obviously, the proposed Pd-CuO/MWCNTs/GCE electrochemical sensor had an excellent linear range, $L O D$, and $L O Q$ values comparable to reported values in the literature. Therefore, the CuO/MWCNTs/GCE sensor has good constancy and high electron kinesis to consider as an alternative electrochemical sensor.

The repeatability of the established $\mathrm{Pd}-\mathrm{CuO} / \mathrm{MWCNTs/}$ GCE sensor was verified by taking five successive determinations with a fixed amount of $6.0 \mu \mathrm{g} \cdot \mathrm{mL}^{-1}$ of ametridione on the same day under ideal conditions. The Pd-CuO/MWCNTs/GCE sensor achieved in retaining $98.0 \%$ of the initial peak response on average peak current. These findings validated the advanced $\mathrm{Pd}$ CuO/MWCNTs/GCE sensor high repeatability, large surface area, and precision. The difference between measurements taken under different conditions on a subject is referred to as reproducibility. In the voltammetric signals, minimal variations with an equivalent standard deviation value (RSD) of $1.72 \%$ were observed within the day at ambient temperatures. In addition, the electrode reproducibility was persistently ex-

Table 2. Application of the recommended method to the determination of ametridione in water samples.

\begin{tabular}{lllll}
\hline Sample & $\begin{array}{l}\text { Amount added } \\
\left(\boldsymbol{\mu g} \cdot \mathbf{m L}^{-1}\right)\end{array}$ & $\begin{array}{l}\text { Amount found } \\
\left(\boldsymbol{\mu g} \cdot \mathbf{m L}^{-1}\right)\end{array}$ & $\begin{array}{l}\text { Recovery* } \\
(\mathbf{\%})\end{array}$ & $\begin{array}{l}\text { Standard } \\
\text { deviation }\end{array}$ \\
\hline \multirow{2}{*}{ Tap water } & 10.0 & 9.80 & 98.0 & 0.014 \\
& 25.0 & 24.6 & 98.4 & 0.025 \\
\hline \multirow{2}{*}{ Agricultural run-off Water } & 10.0 & 9.99 & 99.9 & 0.450 \\
& 25.0 & 24.9 & 99.6 & 0.160 \\
\hline \multirow{2}{*}{ River water } & 10.0 & 9.92 & 99.2 & 0.065 \\
\end{tabular}

${ }^{*} \mathrm{n}=5$ (no. of determinations)

Table 3. Comparison of the proposed electrochemical sensor with the reported electrochemical sensors for the electrochemical analysis of various pesticides.

\begin{tabular}{lllll}
\hline Technique & Modified electrode & $\begin{array}{l}\text { Linear concentration } \\
\text { range }\end{array}$ & $\begin{array}{l}\text { Limit of } \\
\text { detection }\end{array}$ & Ref. \\
\hline DPV & $\mathrm{CPE}$ & $6.7-117.4 \mu \mathrm{M}$ & $2.04 \mu \mathrm{M}$ & Papp et al., 2009 \\
$\mathrm{CV}$ & $\mathrm{NH}_{2}$-SBA-15/CPE & $0.3-18 \mu \mathrm{M}$ & $0.05 \mu \mathrm{M}$ & Thiago et al., 2016 \\
SWV & $\mathrm{PGC}$ & $1.25-100 \mu \mathrm{M}$ & $2.8 \mu \mathrm{M}$ & Brahim et al., 2018 \\
$\mathrm{CV}$ & $\mathrm{GCE}$ & $10.9-1956 \mu \mathrm{M}$ & $30.1 \mu \mathrm{M}$ & Guzsvany et al., 2005 \\
SWV & $\mathrm{MWCNT/GCE}$ & $0.2-60 \mu \mathrm{M}$ & $0.08 \mu \mathrm{M}$ & Salehzadesh et al., 2016 \\
$\mathrm{DPV}$ & $\mathrm{SiO} / \mathrm{MWCNTS/RuPc}$ & $3-66 \mu \mathrm{M}$ & $1.62 \mu \mathrm{M}$ & Canevari et al., 2016 \\
DPV & $\mathrm{Pd}-\mathrm{CuO} / \mathrm{MWCNTs/GCE}$ & $0.1 \mathrm{to} 10.0 \mu \mathrm{g} \cdot \mathrm{mL}^{-1}$ & $0.0796 \mu \mathrm{g} \cdot \mathrm{mL}^{-1}$ & Present Work \\
\hline
\end{tabular}

CPE: carbon paste electrode; $\mathrm{NH}_{2}$-SBA-15/CPE: Amino-functionalized SBA-15/carbon paste electrode; SWV: Square wave voltammetry; PGC: pre-treated glassy carbon electrode; $\mathbf{S i O}_{2} / \mathbf{M W C N T s / R u P c : ~ r u t h e n i u m ~ p h t h a l o c y a n i n e ~ o n ~ s i l i c a - c o a t e d ~ m u l t i - w a l l e d ~ c a r b o n ~}$ nanotubes. 
amined over the course of three days, and the RSD level was discovered to be $\sim 1.4 \%$. This study exposes the modification of glassy carbon electrodes with $\mathrm{Pd}$ CuO/MWCNTs nanoparticles, showing greater constancy and reproducibility.

\section{Conclusion}

The electrochemical reduction of ametridione pesticide in water (river water, tap, agricultural run-off) samples were achieved successfully by differential pulse voltammetry. An electrochemical sensor of Pd-CuO/MWCNTs can be easily prepared and fabricated on a glassy carbon electrode for ametridione detection. The proposed sensor has shown to be a fairly efficient technique for rapid and sensitive determination of ametridione pesticide at a glassy carbon electrode improved with palladium supported multiwalled carbon nanotubes. The obtained $\mathrm{Pd}-\mathrm{CuO} / \mathrm{MWCNTs}$ sensor possessed a decent morphology with fast electron-transport and enabled advantageous electrocatalytic behaviour to reduce ametridione with relatively low detection and quantitation limits. Sensing features of Pd-CuO/MWCNTs/GCE towards ametridione were found to be superior in comparison to the bare GCE, MWCNTs/GCE, CuO/GCE and $\mathrm{Pd} / \mathrm{GCE}$, respectively. The $\mathrm{Pd}-\mathrm{CuO} / \mathrm{MWCNTS} /$ GCE electrochemical sensor offered a low detection limit, quantification limit, good reproducibility, easy construction and short response time for the reduction of ametridine.

\section{Conflict of interest}

The authors declare that they have no conflict of interest.

\section{REFERENCES}

1. Baghayeri, M., Amirhassan, A., Maryam, F., Marzieh, N. \& Ali, E. (2021). Electrochemical detection of bisphenol a on a MWCNTs $/ \mathrm{CuFe}_{2} \mathrm{O}_{4}$ nanocomposite modified glassy carbon electrode. Materials Chemistry and Physics, 261, 124247. https://doi.org/10.1016/j.matchemphys.2021.124 247.

2. Beckie, H.J., Harker, K.N., Hall, L.M., Warwick, S.I., Legere, A., Sikkema, P.H., Clayton, G.W., Thomas, A.G., Leeson, J.Y., Seguin-Swartz, G. \& Simard, M.J. (2006). A decade of herbicide-resistant crops in Canada. Canadian Journal of Plant Science, 86,1243-1264. https://doi.org/1 0.4141/P05-193.

3. Ben Ali Hassine, C. \& Barhoumi, H. (2018). Electrochemical study of a glassy carbon electrode modified by poly-4nitroaniline-reduced/murexide and its sensitivity for metal ions. Analytical Biochemistry, 560, 30-38. https://doi.org/1 0.1016/j.ab.2018.08.023.

4. Bhvimane, S.J., Mruthyunjayachari, C.D., Malathesh, P., Mounesh, P., Sharankumar, T.M. \& Venugopala Reddy, K.R. (2019). Electrochemical sensing based MWCNTCobalt tetra substituted sorbaamide phthalocyanine onto the glassy carbon electrode towards the determination of 2 -Amino phenol: A voltammetric study, Sensors and Actuators B: Chemical, 301, 127078. https://doi.org/10.1016/j.sn b.2019.127078.

5. Brahim, M.B., Elahmadi, M.F., Ammar, H.B. \& Samet, Y. (2018) Determination of ultra-trace amounts of neonicotinoid insecticide imidacloprid by cyclic and square wave voltammetric methods using pretreated glassy carbon electrode. Glob. Nest J. 20, 628-636. https://doi.org/10.30 955/gnj.002509.

6. Canevari, T.C., Prado, T.M., Cincotto, F.H. \& Machado, S.A.S. (2016) Immobilization of ruthenium phthalocyanine on silica-coated multi-wall partially oriented carbon nanotubes: Electrochemical detection of fenitrothion pesticide. Mater. Res. Bull. 76, 41-47, http://dx.doi.org/10.1016/j.ma terresbull.2015.12.007.

7. Choudhury, P.P., Singh, R., Ghosh, D. \& Sharma, A.R. (2016). Herbicide use in Indian agriculture. ICARDirectorate of Weed Research, Jabalpur, Madhya Pradesh, 110.

8. Costa, D.J.E., Santos, J.C.S., Sanches-Brando, F.A.C., Ribeiro, W.F., Salazar-Banda, G.R. \& Araujo, M.C.U. (2017). Boron-doped diamond electrode acting as a voltammetric sensor for the detection of methomyl pesticide, Journal of Electroanalytical Chemistry, 789, 100-107. https://doi.org/10.1016/j.jelechem.2017.02.036.

9. Dan, Du., Xiaxue, Ye., Jie, Cai., Juan, Liu. \& Aidong, Z. (2010). Acetylcholinesterase biosensor design based on carbon nano tube-encapsulated polypyrrole and polyaniline copolymer for amperometric detection of organophosphates, Biosens. Bioelectron., 25, 2503-2508. https://doi.o rg/10.1016/j.bios.2010.04.018.

10. Esmail, S., Amir, H.K., Shahdost-fard, F., Ebrahim, N., Plonska-Brzezinska, M.E., Rahimi-Nasrabadi, M. \& Farhad, A. (2020). A glassy carbon electrode modified with carbon nanoonions for electrochemical determination of fentanyl, Materials Science and Engineering, C, 110, 110684. https://doi.org/10.1016/j.msec.2020.110684.

11. Forouzesh, A., Zand, E., Soufizadeh, S. \& Foroushani, S.S. (2015). Classification of herbicides according to chemical family for weed resistance management strategies - an update. European Weed Research Society, 55, 334-358. https://doi.org/10.1111/wre.12153.

12. Gamze, E. \& Ersin karagozler, A. (1997). Investigation and comparison of the electrochemical behaviour of some organic and biological molecules at various conducting polymer electrodes, Talanta 44, 2011-2018. https://doi.o rg/10.1016/S0039-9140(96)02196-0.

13. Gonçalves-Filho, D., Gonçalves Silva, C.C. \& De Souza, D. (2020). Pesticides determination in foods and natural waters using solid amalgam-based electrodes: Challenges and trends, Talanta, 212, 120756. https://doi.org/10.1016/ j.talanta.2020.120756.

14. Guzsvany, V.J., Gaal, F.F., Bjelica, L.J. \& Okresz, S.N. (2005). Voltammetric determination of imidacloprid and thiamethoxam. J. Serbian Chem. Soc., 70, 735-743. https://doi.org/10.2298/JSC0505735G.

15. Ha, T.J., Hong, M.H., Park, C.S. \& Park, H.H. (2013). Gas sensing properties of ordered mesoporous $\mathrm{TiO}_{2}$ film enhanced by thermal shock induced cracking. Sens. Actuator B Chem, 181, 874-879. https://doi.org/10.1016/j.snb.2 013.02.093. 
Bebi, V. et al. / J. Appl. \& Nat. Sci. 13(3), 798 - 806 (2021)

16. Jian-Chun, Ma. \& Wei-De, Z. (2011). Gold nanoparticlecoated multiwall carbon nanotube-modified electrode for electrochemical determination of methyl parathion, Microchim Acta, 175, 309-314. https://doi.org/10.1007/s00604011-0681-5.

17. Khadem, M., Fardbod, F., Norouzi, P., Abbas Rahimi, F., Mohammad Reza, G., Rasoul, Y. \& Seyed, J.S. (2020). Voltammetric determination of carbofuran pesticide in biological and environmental samples using a molecularly imprinted polymer sensor, a multivariate optimization, Journal of Analytical Chemistry, 75 (5), 669-678. https:// doi.org/10.1134/S1061934820050068.

18. Kniss, A.R. (2017). Long-term trends in the intensity and relative toxicity of herbicide use, Nature Communications, 8 (14865), 1-7. https://doi.org/10.1038/ncomms14865.

19. Koksoy, B., Akyuz, D., Senocak, A., Durmus, M. \& Demirbas, E. (2021). Sensitive, simple and fast voltammetric determination of pesticides in juice samples by novel BODIPY-phthalocyanine-SWCNT hybrid platform, Food and Chemical Toxicology, 147, 1118886. https:// doi.org/10.1016/j.fct.2020.111886.

20. Legere, A., Beckie, H.J., Stevensorn, F.C. \& Thomas, A.G. (2000). Survey of management practices affecting the occurrence of wild oat (Avena fatua) resistance to acetyl-CoA carboxylase inhibitors. Weed Technology 14, 366-376. https://doi.org/10.1614/0890-037X(2000)014[036 6:SOMPAT]2.0.CO;2.

21. Nasrollahzadh, M. (2016). Pd/CuO nanoparticles as a highly effective catalyst for the cyanation of aryl halides under ligand-free conditions. Tetrahedron Letters, 57 (3):337-339. https://doi.org/10.1016/j.tetlet.2015.12.019.

22. Papp, Z., Svancara, I., Guzsvany, V., Vytras, K. \& Gaal, F. (2009). Voltammetric determination of imidacloprid insecticide in selected samples using a carbon paste electrode. Microchim. Acta, 166, 169-175. https://doi.org/10.1007/s0 0604-009-0181-z.

23. Pourakbari, Z., Aliakbar, A. \& Sheykhan, M. (2020). A metal-catex composite electrode for determination of paraquat in various samples by Ad-differential pulse cathodic stripping voltammetry, Talanta 212, 120793. https://doi.or g/10.1016/j.talanta.2020.120793.

24. Rayburn, A. L., Moody, D.D. \& Freeman, J.L. (2005). Cytotoxicity of technical grade versus formulations of atrazine and acetochlor using mammalian cells. Bulletin of Environmental Contamination and Toxicology, 75(4), 691698. https://doi.org/10.1007/s00128-005-0807-8.

25. Rich, J.D., Gabriel, S.M. \& Schultz-Norton, J.R. (2012). In vitro effects of herbicides and insecticides on human breast Cells. International Scholarly Research Notices, 2012, 1-9. https://doi.org/10.5402/2012/232461.

26. Salehzadeh, H., Ebrahimi, M., Nematollahi, D. \& Salarian, A.A. (2016). Electrochemical study of fenitrothion and bifenox and their simultaneous determination using multiwalled carbon nanotube modified glassy carbon electrode. J. Electroanal. Chem. 767, 188-194, http://dx.doi.org/1 0.1016/j.jelechem.2016.02.011.

27. Selim, H.M. (2003). Retention and runoff losses of atrazine and metribuzin in soil. Journal of Environmental Quality, 32 (3), 1058-1071. https://doi.org/10.2134/jeq2003.10 58.

28. Sephenson, G.R., Dykstra, M.D., Mclaren, R.D. \& Hamill, A.S., (1990). Agronomic practices influencing triazineresistant weed distribution in Ontario. Weed Technology, 4 (1), 199-207. https://doi.org/10.1017/S0890037X0002 5227.

29. Sira, L.R., de Lima, F., Cardoso, C.A.I. \& Arruda, G.J. (2015). Electrochemically pretreated zeolite-modified carbon-paste electrodes for determination of linuron in an agricultural formulation and water. Electrochemica Acta, 151, 609-618. https://doi.org/10.1016/j.electact a.2014.1 1.008 .

30. Subbalaskhmamma, M. \& Jayarama Reddy, S. (1994). Electrochemical behavior of formetanate and chlordimeform pesticides. Electroanalysis, 6, 612-615. https:// doi.org/10.1002/elan.1140060716.

31. Thiago, C. C., Thiago, M.P., Fernando, H. C. \& Sergio, A.S.M. (2016). Immobilization of ruthenium phthalocyanine on silica-coated multi-wall partially oriented carbon nanotubes: Electrochemical detection of fenitrothion pesticide. Materials Research Bulletin, 76, 41-47. https:// doi.org/10.1016/j.materresbull.2015.12.007.

32. Thiago, M.B.F.O., Francisco W.P.R., Camila P.S., Giancarlo, R.S., Pedro de, L., Adriana N.C. \& Simone, M. (2020). Current overview and perspectives on carbonbased (bio) sensors for carbamate pesticides electroanalysis. TrAC Trends in Analytical Chemistry, 124, 115779. https://doi.org/10.1016/j.trac.2019.115779.

33. Vieira da Silva, L., Nicholas, D.S., Andresa, K.A.A., Dave Di, E.R.S., Ana Caroline, F.S., Mesaque, C.F., Dimas, J.P.L., Phabyanno, R.L. \& Marilia, O.F.G. (2021). A new electrochemical sensor based on oxidized capsaicin/multiwalled carbon nanotubes/glassy carbon electrode for the quantification of dopamine, epinephrine, and xanthurenic, ascorbic and uric acids, Journal of Electroanalytical Chemistry, 881, 114919. https://doi.org/10.1016/j.jelech em.2020.114919. 